\title{
Absence of Whisker-Related Pattern Formation in Mice with NMDA Receptors Lacking Coincidence Detection Properties and Calcium Signaling
}

\author{
York Rudhard, ${ }^{1,2 *}$ Matthias Kneussel, ${ }^{1,2 \star}$ Mohammed A. Nassar, ${ }^{1,2}$ Georg F. Rast, ${ }^{1,2}$ Alexander J. Annala, ${ }^{1,2}$ \\ Philip E. Chen, ${ }^{1,2}$ Cezar M. Tigaret, ${ }^{1,2}$ Isabel Dean, ${ }^{1,4}$ Juergen Roes, ${ }^{5}$ Alasdair J. Gibb, ${ }^{2}$ Stephen P. Hunt, ${ }^{3}$ and \\ Ralf Schoepfer ${ }^{1,2}$ \\ ${ }^{1}$ Wellcome Laboratory for Molecular Pharmacology, ${ }^{2}$ Department of Pharmacology, ${ }^{3}$ Department of Anatomy, ${ }^{4}$ Wellcome Trust Neuroscience PhD \\ program, and ${ }^{5}$ Department of Medicine, University College London, London WC1E 6BT, United Kingdom
}

Precise refinement of synaptic connectivity is the result of activity-dependent mechanisms in which coincidence-dependent calcium signaling by NMDA receptors (NMDARs) under control of the voltage-dependent $\mathrm{Mg}^{2+}$ block might play a special role.

In the developing rodent trigeminal system, the pattern of synaptic connections between whisker-specific inputs and their target cells in the brainstem is refined to form functionally and morphologically distinct units (barrelettes). To test the role of NMDA receptor signaling in this process, we introduced the N598R mutation into the native NR1 gene. This leads to the expression of functional NMDARs that are $\mathrm{Mg}^{2+}$ insensitive and $\mathrm{Ca}^{2+}$ impermeable.

Newborn mice expressing exclusively NR1 N598R-containing NMDARs do not show any whisker-related patterning in the brainstem, whereas the topographic projection of trigeminal afferents and gross brain morphology appear normal. Furthermore, the NR1 N598R mutation does not affect expression levels of NMDAR subunits and other important neurotransmitter receptors.

Our results show that coincidence detection by, and/or $\mathrm{Ca}^{2+}$ permeability of, NMDARs is necessary for the development of somatotopic maps in the brainstem and suggest that highly specific signaling underlies synaptic refinement.

Key words: barrelette; somatosensory; whisker; trigeminal pathway; pattern formation; topographic map; NMDA receptor; NMDAR; coincidence detection; point mutation; knock-in; homologous recombination; cytochrome oxidase; DiI labeling; $\mathrm{Mg}^{2+}$ block; $^{\mathrm{Ca}^{2+}}{ }_{-}$ dependent signaling; brainstem; Cre recombinase; loxP; Tenascin; boundary

\section{Introduction}

The precise pattern of neuronal connectivity results from both activity-dependent and activity-independent mechanisms (Goodman and Shatz, 1993). Current models implicate coincident activity of independent inputs in the refinement of synaptic connections within developing topographic maps.

The rodent trigeminal pathway is an excellent system to study the molecular mechanisms underlying activity-dependent map formation (Molnar and Hannan, 2000; Erzurumlu and Kind, 2001). Whisker-related sensory inputs are topographically mapped at multiple relay stations from the trigeminal input to

\footnotetext{
Received Sept. 6, 2002; revised Dec. 10, 2002; accepted Dec. 16, 2002.

This work was supported by a Wellcome Trust Senior Fellowship (R.S.). Y.R. and M.A.N. were supported by a Wellcome prize studentship. C.M.T. was supported by a Wellcome Traveling fellowship. G.F.R. is recipient of an Emmy Noether fellowship (Deutsche Forschungsgemeinschaft). We thank K. Rajewsky for DNA plasmids (floxed neo and HSV tk) and E14 ES cells, F. Schwenk and K. Rajewsky for the generous gift of (re Deleter mice, and C. M. Becker, A. Faissner, M. Herkert, and S. J. Moss for antibodies.

*Y.R. and M.K. contributed equally to this work.

Correspondence should be addressed to Ralf Schoepfer, Laboratory for Molecular Pharmacology, Department of Pharmacology, University College London, Gower Street, London WC1E 6BT, UK. E-mail: r.schoepfer@ucl.ac.uk.

A. J. Annala's present address: Pharmacology Department, University of California, Los Angeles School of Medicine, Los Angeles, CA 90095

P. E. Chen's present address: Department of Neuroscience, University of Edinburgh, Edinburgh EH8 9JZ, UK.

I. Dean's present address: Department of Physiology, University College London, London WC1E 6BT, UK.

M. Kneussel's present address: Centre for Molecular Neurobiology, D-20251 Hamburg, Germany.

M. A. Nassar's present address: Department of Biology, University College London, London WC1E 6BT, UK.

Copyright $\odot 2003$ Society for Neuroscience $\quad 0270-6474 / 03 / 232323-10 \$ 15.00 / 0$
}

the primary sensory cortex. At each level, presynaptic afferents and postsynaptic target cells form discrete cytoarchitectural and functional units that replicate the whisker pattern on the muzzle in a one-to-one relationship (Woolsey and Van der Loos, 1970; Van der Loos, 1976; Ma and Woolsey, 1984; Woolsey, 1990).

Whisker-related patterns develop along a peripheral to central temporal gradient (Woolsey, 1990). At birth, patterning can be detected by staining for cytochrome oxidase (CO) at the first central synapse of the pathway, located in the brainstem trigeminal complex (BSTC) (Ma, 1993; Li et al., 1994; Jhaveri et al., 1998). Pattern formation then progresses to thalamic barreloids, followed by cortical barrels.

Coincidence detection-dependent calcium signaling by NMDA receptors (NMDARs) may be crucial in activitydependent synaptic refinement. The role of NMDAR-mediated activity in the development of whisker-related patterns has been studied pharmacologically and genetically. Local application of the NMDAR antagonist APV disrupted the topographic refinement of thalamocortical connectivity (Schlaggar et al., 1993; Fox et al., 1996). Deletion of the NMDAR NR1 or NR2B gene prevents the formation of barrelettes in the brainstem ( $\mathrm{Li}$ et al., 1994; Kutsuwada et al., 1996; Iwasato et al., 1997), and cortex-restricted deletion of the NR1 gene impairs whisker-related patterning in the barrel cortex (Iwasato et al., 2000). Thus, NMDAR-mediated activity is essential for the refinement of whisker-related synaptic 
patterns. However, the relevance of coincidence detection by the NMDAR has not been addressed so far.

Special biophysical properties enable the NMDAR to act as coincidence detector (Bourne and Nicoll, 1993). Removal of the channel-blocking $\mathrm{Mg}^{2+}$ ion by postsynaptic depolarization in synchrony with presynaptically released glutamate is necessary to open the NMDAR channel. The $\mathrm{Ca}^{2+}$ signal generated by such a coincidence event may trigger signaling cascades, ultimately leading to changes in synaptic connectivity (Goodman and Shatz, 1993).

Both $\mathrm{Mg}^{2+}$ block and $\mathrm{Ca}^{2+}$ permeability are abolished by the $\mathrm{N}$ (Asp) to $\mathrm{R}$ (Arg) point mutation at the $\mathrm{Q} / \mathrm{R} / \mathrm{N}$ site in the channel-lining region of membrane domain M2 (Burnashev et al., 1992; Sakurada et al., 1993). NMDARs are heterooligomers formed from developmentally and regionally regulated NR2 subunits (A to D) and the mandatory NR1 subunit (for review, see Cull-Candy et al., 2001). Thus, the introduction of the N598R mutation in the NR1 subunit (NR1 N598R) impairs coincidence detection and $\mathrm{Ca}^{2+}$ signaling of all NMDARs.

Using homologous recombination in embryonic stem (ES) cells, we now generated a mouse model with NR1 N598R mutant NMDARs. We found that whisker-related somatosensory pattern formation (barrelettes) is impaired in these mice. Our results show that the presence of functional NMDARs is not sufficient for this type of pattern formation when their $\mathrm{Mg}^{2+}$ block and $\mathrm{Ca}^{2+}$ permeability are impaired.

\section{Materials and Methods}

Animal procedures. Mice were kept at the Biological Services Unit of the University College London, and procedures on mice were performed according to the Animal Scientific Procedures Act of 1986 and under license of the Home Office.

Generation and analysis of mutant alleles and mice. The NR1 N598R targeting vector was constructed from 129 SVJ mouse genomic DNA (Stratagene, La Jolla, CA).

A four-primer PCR created a fragment from exons 14 to 17, harboring the N598R mutation, silent mutations at codon 599, a diagnostic AvaII site overlapping codon 598/599, and a silent SalI site in exon 14 (oligos always in 5'-3' notation, GluN-PCR25s (CCTTTCAGTCGACACTGTGGCTGCTGGTGGGGC), GluN-PCR26a (AGCCACAGTGTCGACTGAAAGGGCTGCATGAATG), GluNPCR6a (CAGGACGCCCCAGGAAAACCACAT), and GluN-Mut2s (GTGGTTTTCCTGGGGCGTCCTGCTGCGGTCCGGC).

The floxed herpes simplex virus promoter (HSV)-neo selection cassette from pL2-neo ${ }^{\mathrm{r}}$ was inserted into the BamHI site in intron 18. The HSV-tk selection cassette from pIC19R/MC1-TK (Mansour et al., 1988) was added $5^{\prime}$ to the NR1 targeting sequences. The final targeting vector had a $6.2 \mathrm{~kb}$ long $5^{\prime}$ arm and a $0.9 \mathrm{~kb}$ short $3^{\prime}$ arm flanking the $1.3 \mathrm{~kb}$ floxed neo cassette and was linearized $3^{\prime}$ of the NR1 sequences.

Transfected embryonic day 14 (E14) ES cells (Handyside et al., 1989) that were G418 resistant were screened for homologous recombination by PCR [primers Neo-Seq-1 (GGTGTTGGTCGTTTGTTCGGATCT) and mNR1-PCR-26a (TGGTGTCAGAGGTGCTTGGATGAT)]. The presence of mutations at codons 598/599 were confirmed by AvaII digests and sequencing of PCR-products [primers mNR1-Seq-29s (TCCCTTTGGCCGATTTAAGGTGAA) and mNR1-Seq-30a (GAAAGCTGGGAATGCAGCCATCCA)]. PCR-positive clones were verified by Southern blot analysis of SpeI/XbaI-digested ES cell DNA (probe: SacII/KpnI cDNA fragment binding to exon 8 and exon 9) and of SalI/ BglII digests (probe B: the genomic ApaI/SmaI fragment, introns 20 and 21). Probe B was also used on blots of EcoRV-digested mouse tail DNA as shown in Figure 1.

In addition, a neo and a HSV-tk probe were used to exclude additional random integration of the targeting vector. Correctly targeted ES cell clones were injected into C57BL/6J blastocysts, and chimeric animals were backcrossed with $\mathrm{C} 57 \mathrm{BL} / 6 \mathrm{~J}$ mice to yield NR1 ${ }^{+/ R n e o}$ animals. Mating $\mathrm{I}$ is $\mathrm{NR} 1^{+/ \text {Rneo }} \times \mathrm{NR} 1^{+/ \text {Rneo }}$.

Mice with the NR1 null allele $\left(\mathrm{NR} 1^{+/-}\right.$) were produced likewise (details to be described elsewhere) by insertion of an $8 \mathrm{~kb}$ large DNA cassette containing the HSV-neo gene into exon 1 upstream of the NR1 coding sequence. Probe A (Bsu36I/XhoI DNA fragment, $5^{\prime}$ of exon 1) was used on blots of EcoRV-digested mouse tail DNA for genotyping.

Generation of mice with five different NR1 genotypes. NR1 ${ }^{+/ R n e o}$ $\mathrm{NR} 1^{+/-}$, and "Deleter" mice carrying an X-chromosomally linked transgene for the recombinase Cre from bacteriophage (Schwenk et al., 1995) were each backcrossed with C57BL/6J to at least F6 generation.

Genotyping was done by PCR on mouse tail DNA, after the assay had been verified by genomic Southern blots. The Cre transgene yielded a 486 bp product [primers Cre-Seq1-s (AGATGTTCGCGATTATCTTCTA) and Cre-Seq2-a (AGCTACACCAGAGACGG)]. NR1 ${ }^{+/-}$mice were intercrossed (mating III) to yield NR $1^{-1-}$ mice [primers mNR1-Seq38-s (ACCAGTCGCACAGTCCAGGCAGCT) together with GluN-Seq3a (GGCGTTGAGCTGTATCTTCC) and TA-Seq2-a (CTAGCTTCTGGGCGAGTTTACGGGT); wild-type product, 404 bp; null allele product, $323 \mathrm{bp}$ ].

Global activation of the NR1 N598R allele by mating NR1 ${ }^{+/ R n e o}$ mice with Deleter mice is dominant lethal. Thus, to generate mice exclusively expressing the NR1 N598R mutant allele, female Deleter $\mathrm{Cre}^{+/+}$mice were first bred with $\mathrm{NR} 1^{+/-}$mice to obtain $\mathrm{NR} 1^{+/-} / \mathrm{Cre}^{+/-}$mice. Backcrossing of $\mathrm{NR}^{+/-} / \mathrm{Cre}^{+/-}$with $\mathrm{Cre}^{+/+}$mice yielded NR1 $1^{+/-}$/ $\mathrm{Cre}^{+/+}$mice. Female NR $1^{+/-} / \mathrm{Cre}^{+/+}$mice were mated overnight with male NR1 ${ }^{+/ R n e o}$ mice (mating II) to obtain $\mathrm{NR} 1^{\mathrm{R} /-}$ mice along with $\mathrm{NR} 1^{\mathrm{R} /+}, \mathrm{NR} 1^{+/-}$, and $\mathrm{NR} 1^{+++}$mice.

The morning after the mating was referred to as E0. All four genotypes could be distinguished by multiplex PCR using primers 1 (mNR1Seq103-s, GTCCATACTCAAGTGAGTCTGCCC), 2 (mNR1-Seq10-a, CAGGGGCATTGCTGCGGGAGTC), 3 (Neo-Seq4-s, GCTGCATACGCTTGATCCGGCTACC), and 4 (Neo-Seq3-a, GAAGGCGATAGAAGGCGATGCGC), generating 508 and 615 bp PCR products for the $\mathrm{NR} 1^{+}$and $\mathrm{NR} 1^{\mathrm{R}}$ alleles, respectively (the increase in size in $\mathrm{NR} 1^{\mathrm{R}}$ is attributable to the remaining loxP site and adjacent polylinker sequence), and $414 \mathrm{bp}$ for the neo cassette, indicating the knock-out allele.

$m R N A$ quantification. Reverse transcription (RT)-PCR (Ready-to-Go RT-PCR; Amersham Biosciences, Arlington Heights, IL) (oligo-dT primed first strand) was performed on total RNA from postnatal day 0 (P0) whole brain from $\mathrm{NR} 1^{\mathrm{R} /+}$ mice, using the primers $\mathrm{mNR} 1-\mathrm{PCR} 101 \mathrm{~s}$ (CAGGGTACCTCCCTTTGGCCGATTTAAGGTGAA) and mNR1PCR104a (TGAGAATTCCAGGGGCATTGCTGCGGGAGTC). The resulting amplicons of $665 \mathrm{bp}$ covering exons $14-19$ of the NR1 allele were subcloned into M13.

Phage plaques harboring NR1 ${ }^{+}$or NR $1{ }^{\mathrm{R}} \mathrm{cDNA}$ inserts, respectively, were quantified by differential oligonucleotide hybridization $\left(42^{\circ} \mathrm{C}\right.$ in $50 \%$ formamide; followed by final stringency wash in $0.3 \times$ SSPE $[1 \times$ SSPE (in mM): $150 \mathrm{NaCl}, 10 \mathrm{NaH}_{2} \mathrm{PO}_{4}$, and 1 EDTA, pH 7.4] at $60^{\circ} \mathrm{C}$ ) with oligonucleotides mNR1-Is3-a, (CCCCAATGCCAGAGTTGAGCAGGACGCCCCAG) and mNR1-Is4-a (CCCCAATGCCgGAccgcAGCAGGACGCCCCAG) for wild-type and mutant alleles, respectively (Higuchi et al., 1993). The relative abundance of NR1 ${ }^{+}$and NR $1^{\mathrm{R}}$ transcripts was determined as the ratio of the number of plaques hybridizing with one probe to the total number of NR1 transcript-containing plaques. A number of $\mathrm{NR}^{+}{ }^{+}$- and $\mathrm{NR} 1^{\mathrm{R}}$ - containing plaques were verified by DNA sequencing.

Northern blot analysis. Poly $\left(\mathrm{A}^{+}\right) \mathrm{RNA}$ was prepared from whole brain of newborn mice, and Northern blot analysis was performed as described previously (Specht and Schoepfer, 2001) using a 318 bp cDNA fragment binding to NR1 exons 15-17. Reprobing with a $0.9 \mathrm{~kb}$ actin cDNA fragment served as control for equal loading.

Western blot analysis. Membrane protein fraction was prepared from frozen P0 brain of genotyped mice as described previously (Forrest et al., 1994), except that $100 \mathrm{mg}$ of tissue were homogenized in $2 \mathrm{ml}$ volume, and protein degradation was inhibited using Complete protease inhibitor cocktail (Roche Products, Hertforshire, UK). Protein concentrations were determined by the Bio-Rad (Hercules, CA) DC protein assay.

For SDS-PAGE, samples containing $50 \mu \mathrm{g}$ of protein were supple- 
mented with equal volumes of protein sample buffer [ $62.5 \mathrm{~mm}$ Tris- $\mathrm{HCl}$, pH 6.8, 2\% SDS, 20 mm DTT, 10\% glycerol, and 0.003\% (w/v) Pyronin$\mathrm{Y}$ ], samples were incubated at $50^{\circ} \mathrm{C}$ for $15 \mathrm{~min}$, and urea was added to samples to a final concentration of $4 \mathrm{M}$. SDS-PAGE on $6 \%$ gels was followed by electrotransfer onto polyvinylidene difluoride membrane (Hybond-P; Amersham Biosciences). Immunodetection was performed as described previously (Specht and Schoepfer, 2001), with primary antibodies used at the appropriate dilution: rabbit (rb) anti-NR1, 1:500 (G8913; Sigma, St. Louis, MO); rb anti-NR2A, 1:750 (AB1555P; Chemicon, Temecula, CA); rb anti-NR2B, 1:1000 (AB1557P; Chemicon); rb antiNR2C, 1:100 [serum K21450, raised against amino acids (aa) 434-447; M. Herkert, University of Erlangen, Erlangen, Germany]; rb anti-NR2D, 1:1000 (serum K23, aa 1046-1062; M. Herkert); rb anti-ionotropic glutamate receptor subunit 1 (GluR1), 1:1000 (AB1504; Chemicon), rb anti-GluR2/3, 1:5000 (AB1506; Chemicon); rb anti-GluR4, 1:100 (AB1508; Chemicon); mouse anti-metabotropic GluR1 $\alpha$ (mGluR1 $\alpha)$, 1:500 (number 556331; BD Phar-Mingen); rb anti-GABA $A_{A} \mathrm{R}-\beta_{3}, 1: 5000$ (Brandon et al., 2000); and guinea pig anti-GABA $\mathrm{A}-\mathrm{g}_{2}, 1: 200$ (Brandon et al., 2001).

Specific immunoreactivity was detected using enhanced chemiluminescence (ECL Plus; Amersham Biosciences).

Tissue culture and electrophysiology. Hippocampal organotypic slice cultures were prepared from embryos at stage E18.5-E19.5 as described previously (Stoppini et al., 1991). Briefly, embryos were decapitated, and the brain was removed from the skull and placed into ice-cold dissecting medium (MEM 22370-027, including 100U/ml penicillin and $100 \mu \mathrm{g} / \mathrm{ml}$ streptomycin; Invitrogen, Gaithersburg, MD). Hippocampi were dissected out, and tissue slices were taken at $350 \mu \mathrm{m}$ using a conventional tissue chopper (McIlwain). Slices were placed on Millicell (Millipore, Bedford, MA) $35 \mathrm{~mm}$ tissue culture inserts with membranes $(0.4 \mu \mathrm{m}$ pore diameter) supplied with prewarmed culture medium [two parts MEM and one part HBSS (24020-091; Invitrogen), one part heatinactivated horse serum (26050-070; Invitrogen), $100 \mathrm{U} / \mathrm{ml}$ penicillin, and $100 \mu \mathrm{g} / \mathrm{ml}$ streptomycin]. Cultures were then held in a moistened atmosphere containing $5 \% \mathrm{CO}_{2}$ at $37^{\circ} \mathrm{C}$ for up to 3 weeks.

After at least $7 \mathrm{~d}$ in culture, slices were placed in a recording chamber perfused with artificial CSF (aCSF) [in mM: $126 \mathrm{NaCl}, 2.5 \mathrm{KCl}, 1 \mathrm{CaCl}_{2}$, $1.2 \mathrm{NaH}_{2} \mathrm{PO}_{4}, 26 \mathrm{NaHCO}_{3}$, and 20 glucose, pH 7.4 (saturated with $95 \%$ $\mathrm{O}_{2}-5 \% \mathrm{CO}_{2}$ )] containing $200 \mathrm{~nm}$ TTX, $10 \mu \mathrm{m}$ bicuculline methiodide, 1 $\mu \mathrm{M}$ strychnine, and $5 \mu \mathrm{M}$ DNQX. Whole-cell patch recordings were obtained with glass pipettes filled with recording solution [in $\mathrm{mm}: 130 \mathrm{CsCl}$, $2.5 \mathrm{NaCl}, 5 \mathrm{MgCl}_{2}, 10 \mathrm{HEPES}$, and 10 EGTA, pH 7.2 with $\mathrm{CsOH}(4-6$ $\mathrm{M} \Omega$ resistance)] using an Axopatch $2 \mathrm{~B}$ or $200 \mathrm{~A}$ amplifier. Bath application of aCSF containing either [20 $\mu \mathrm{M}$ NMDA] or [20 $\mu \mathrm{M}$ NMDA plus 500 or $100 \mu \mathrm{M} \mathrm{Mg}^{2+}$ ] or, as a control, [20 $\mu \mathrm{M} \mathrm{NMDA,} 500$ or $100 \mu \mathrm{M}$ $\mathrm{Mg}^{2+}$, and $\left.20 \mu \mathrm{M} \mathrm{APV}\right]$, plus $10 \mu \mathrm{M}$ glycine at all times, was accomplished using an ALA Scientific Instruments (Westbury, NY) and NPI Electronics (Tamm, Germany) Multivalve system. Cells were held at -60 $\mathrm{mV}$ (series resistance was compensated at 95\%), and $I-V$ curves before, during, and after application of the respective combination of drugs were established by a ramp protocol covering the range from -100 to $40 \mathrm{mV}$. Data acquisition and control of the experimental protocol was done using the National Instruments (Austin, TX) PCI-MIO-16XE-10 board and an INT-20 interface and CellWorks software (NPI Electronics). For data evaluation, IGOR (WaveMetrics, Lake Oswego, OR) software was used.

Histology. Pups were injected intraperitoneally with an overdose of sodium pentobarbitone, and death was confirmed by absence of pawwithdrawal reflex. Next, mice were transcardially perfused with cold 0.1 M phosphate buffer (PB), $\mathrm{pH} 7.4$, followed by $4 \%$ paraformaldehyde in $1 \times$ PBS. P0 pups were postfixed overnight in toto.

For Nissl staining, fixed brains were dissected out and equilibrated in $30 \%$ sucrose- $0.1 \mathrm{M} \mathrm{PB}, \mathrm{pH}$ 7.4. Transverse-coronal sections were cut with a cryostat $(10-15 \mu \mathrm{m})$ or a freezing microtome $(50 \mu \mathrm{m})$, respectively, and mounted on gelatinized slides. Mounted sections were dried overnight, soaked in tap water for $10 \mathrm{~min}$, stained in $0.05 \%$ thionin solution (BDH Laboratory Supplies, Poole, UK), washed in tap water, differentiated in 95\% ethanol, dehydrated in an ethanol series (70, 90, and $100 \%$ ), cleared in Histoclear (National Diagnostics, Atlanta, GA), and coverslipped in DPX (BDH Laboratory Supplies).
CO staining was performed as described previously (Wong-Riley, 1979). Pups were prepared as described above and sucrose equilibrated in toto. Serial $50 \mu \mathrm{m}$ transverse brainstem sections were cut from whole heads using a freezing microtome and collected in $0.1 \mathrm{M} \mathrm{PB}, \mathrm{pH}$ 7.4. Sections were transferred into CO staining solution [0.1 м PB, pH 7.4, $4 \%$ sucrose, $0.4 \%$ cytochrome $c$ (C-7752; Sigma), and $0.5 \%$ diaminobenzidine] and incubated for $2-4 \mathrm{hr}$ in a $37^{\circ} \mathrm{C}$ incubator. Reactions were stopped by transferring sections into $0.1 \mathrm{M} \mathrm{PB}, \mathrm{pH}$ 7.4. Sections were rinsed in $0.01 \mathrm{M} \mathrm{PB}, \mathrm{pH} 7.4$, mounted on gelatinized slides, and processed as above without Nissl staining. Each CO staining experiment included at least one wild-type positive control from the same litter.

For Tenascin-C (TN-C) immunostaining, affinity-purified IgG fraction of a polyclonal rabbit antiserum raised against complete Tenascin- $C$ (Faissner and Kruse, 1990) was used at 1:15000 and visualized with biotinylated goat anti-rabbit antibody at 1:600 (BA-1000; Vector Laboratories, Burlingame, CA), followed by the Vectastain Elite ABC kit (1:600).

DiI labeling. For axonal labeling of primary trigeminal afferents (Erzurumlu and Jhaveri, 1992), small crystals of DiI (Molecular Probes, Eugene, OR) were applied to single whiskers under visual control, i.e., to follicle $\mathrm{B} 1$ on one side and $\mathrm{B} 2$ on the opposite side of the face of fixed pups. Pups were kept in fixative at $37^{\circ} \mathrm{C}$ for at least 3 months for the dye to diffuse. Brains were carefully dissected out and embedded in $40^{\circ} \mathrm{C}$ equilibrated 2\% low-melting-point agarose (Flowgen). Vibratome-cut $100 \mu \mathrm{m}$ transverse brainstem sections were mounted onto polysine microscrope slides (BDH Laboratory Supplies) and coverslipped with $40^{\circ} \mathrm{C}$ $0.6 \%$ low-melting-point agarose in $1 \times$ PBS. Fluorescent staining was studied using a Zeiss (Oberkochen, Germany) Axiophot Photomicroscope equipped with a rhodamine filter set, followed by confocal microscopy using a Leica (Nussloch, Germany) upright microscope fitted with a Leica TCS SP scan head. DiI-labeled axonal projections in the trigeminal nucleus were visualized by confocal laser scanning microscopy (568 $\mathrm{nm}$ excitation) using a $25 \times, 0.75$ numerical aperture oil immersion objective, $2 \times$ electronic zoom, $4 \times$ scan accumulation, and $0.2 \mu \mathrm{m}$ distance between optical sections. Z-projections (standard deviation method) of image stacks were produced using ImageJ software (http://rsb.info.nih. gov/ij/). The location $(l)$ of a DiI patch in the subnucleus caudalis $(\mathrm{nVc})$ is $l=a / b$, where $a$ is the horizontal distance from center of patch to lateral margin of section, and $b$ is the horizontal distance from midline of section to lateral margin of section.

\section{Results}

\section{Targeted mutation of the NR1 subunit}

Through homologous recombination in ES cells, we altered the DNA sequence coding for amino acid 598 of the mature NR1 subunit. The wild-type codon for the 598 asparagine residue in exon 15 was replaced by a codon for arginine. At the same time, a floxed (flanked by loxP sites in the same orientation) neo selection cassette was introduced into intron 18 , yielding the NR1 ${ }^{\text {Rneo }}$ allele (Fig. 1).

Chimeric mice of wild-type blastocysts and ES cells carrying the NR1 $1^{\text {Rneo }}$ allele produced heterozygous offspring of the $\mathrm{NR} 1^{\text {Rneo/+ }}$ genotype. These NR1 $1^{\text {Rneo/+ }}$ mice were viable and fertile and were backcrossed with C57BL/6J inbred mice for additional experiments.

Homozygous animals of the NR1 $1^{\text {Rneo/Rneo }}$ genotype died within $12 \mathrm{hr}$ after birth. The presence of the neo cassette in exon 18 was found to disrupt the expression of the NR $1{ }^{\text {Rneo }}$ allele (data not shown). Thus, NR1 ${ }^{\text {Rneo/Rneo }}$ mice should have the same phenotype as homozygous NR1 knock-out animals and were therefore not studied further.

\section{Generation of NR1 mutant genotypes}

Cre-mediated excision of the floxed neo cassette in intron 18 of the NR1 Rneo allele converts the inactive neo-containing allele into an active NR1 allele that carries the N598R mutation (NR1 ${ }^{\mathrm{R}}$ allele) (Fig. 1). Mating of NR1 $1^{\text {Rneo/+ }}$ mice with Deleter mice 
A
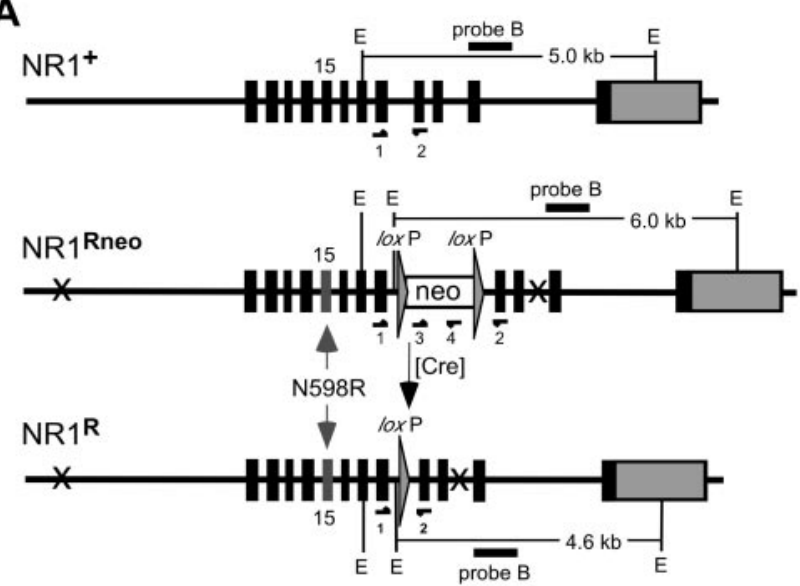

B

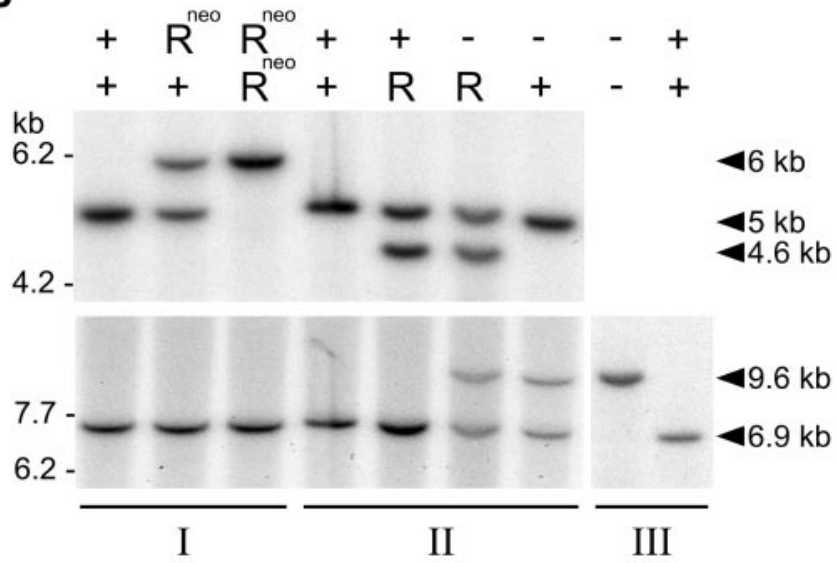

Figure 1. Generation of the NR1 N598R alleles. A, Partial organization of the murine NR1 locus. Wild-type locus $\left(\mathrm{NR}^{+}{ }^{+}\right.$), the targeted locus after homologous recombination (NR1 ${ }^{\text {Rneo }}$ ), and the targeted locus after Cre-mediated excision of the neo cassette $\left(\mathrm{NR} 1^{\mathrm{R}}\right)$. Exons are depicted as boxes. Coding regions are in black, and the $3^{\prime}$ UTR are in gray. Exon 15 harbors the N598R mutation after targeting. loxP elements are shown as filled triangles, and the neo selection marker is shown as an open box. The $5^{\prime}$ and $3^{\prime}$ limits of the targeting construct are indicated $\left(\times\right.$ symbols) on the $\mathrm{NR}^{\mathrm{Rneo}}$ and $\mathrm{NR}^{\mathrm{R}}{ }^{\mathrm{h}}$ alleles. Relevant $E$ coRV $(E)$ restriction sites and DNA fragments, as well as localization of hybridizing probe $B$, are shown. PCR primers 1-4 (see Materials and Methods) for routine genotyping are depicted as horizontal arrows. B, Southern blot of EcoRV-digested genomic mouse tail DNA. Lanes 1-3 show offspring from mating I $\left(\mathrm{NR} 1^{+/ R n e o} \times \mathrm{NR} 1^{+/ R n e o}\right)$, lanes $4-7$ show offspring from mating $I I\left(\mathrm{NR} 1^{+/-} / \mathrm{Cre}^{+/+} \times\right.$ $\left.\mathrm{NR} 1^{+/ \text {Rneo }}\right)$, and lanes 8 and 9 show offspring of mating III (NR1 $\left.{ }^{+/-} \times \mathrm{NR} 1^{+/-}\right)$. Top, The membrane was hybridized with probe $B$ to test for the different mutated NR1 alleles: wild-type $(+$ symbols; $5 \mathrm{~kb})$; targeted $\left(R^{\text {neo }} ; 6 \mathrm{~kb}\right)$; and targeted after Cre-mediated resolution of the neo cassette $(R ; 4.6 \mathrm{~kb})$. Bottom, The membrane was stripped and hybridized with probe A to test for the null allele: wild-type ( + symbols; $6.9 \mathrm{~kb}$ ) and null ( - symbols; $9.6 \mathrm{~kb}$ ) (see Materials and Methods).

(Schwenk et al., 1995) results in mice of the $\mathrm{NR}^{\mathrm{R} /+}$ genotype. These mice express comparable amounts of $\mathrm{NR}^{+}$and NR1 ${ }^{\mathrm{R}}$ mRNA, as shown by M13 plaque assays ( $\mathrm{NR} 1^{+}$plaques, $52.3 \pm$ $1.3 \%$; NR $1{ }^{\mathrm{R}}$ plaques, $47.7 \pm 1.3 \% ; n=3$; means $\pm \mathrm{SD}$ ).

Because of the lethal phenotype of NR1 ${ }^{\mathrm{R} /+}$ (see below), it is not possible to generate NR1 ${ }^{\mathrm{R} / \mathrm{R}}$ mice. To obtain mice that express only NR1 ${ }^{\mathrm{R}}$ mRNA (and no wild-type NR1 mRNA), $\mathrm{NR} 1^{\mathrm{Rneo} /+}$ mice were mated with $\mathrm{Cre}$ mice $\left(\mathrm{Cre}^{+/+}, \mathrm{NR} 1^{+/-}\right)$ that carried in addition an NR1 null allele, $\mathrm{NR}^{-}$. The breeding scheme results in a total of four different NR1 genotypes $\left(\mathrm{NR} 1^{+/+}, \mathrm{NR} 1^{\mathrm{R} /+}, \mathrm{NR} 1^{\mathrm{R} /-}\right.$, and $\left.\mathrm{NR} 1^{+/-}\right) . \mathrm{NR} 1^{-/-}$mice were generated by mating $\mathrm{NR} 1^{+/-}$mice.

\section{The N598R mutation is dominant lethal}

$\mathrm{NR} 1{ }^{\mathrm{R} /+}$ mice were found to die within $6 \mathrm{hr}$ from birth. They were in respiratory distress and displayed motor hyperactivity to the extent that they did not remain in a seated position but rolled over when placed on their limbs.

$\mathrm{NR} 1^{\mathrm{R} /-}$ mice were found to have an even more severe phenotype than $\mathrm{NR} 1^{\mathrm{R} /+}$ and $\mathrm{NR} 1^{-1-}$ mice; they hardly moved or breathed, became cyanotic shortly after birth, and died within 1 hr. Thus, both NR1 $1^{\mathrm{R} /+}$ and NR1 $1^{\mathrm{R} /-}$ genotypes differ phenotypically from $\mathrm{NR} 1^{+/-}$and $\mathrm{NR} 1^{-/}$genotypes. $\mathrm{NR} 1^{+/-}$mice appeared normal, whereas $\mathrm{NR} 1^{-/-}$mice passed from a phenotypically normal to a morbid phase and died within $12-20 \mathrm{hr}$ as a result of respiratory failure (Forrest et al., 1994; Li et al., 1994; Poon et al., 2000).

Mice with $\mathrm{NR} 1^{\mathrm{R} /+}, \mathrm{NR} 1^{\mathrm{R} /-}, \mathrm{NR} 1^{+/-}$, and $\mathrm{NR} 1^{-/-}$genotypes had normal body weights at birth compared with NR1 ${ }^{+/+}$ mice. Newborn pups of all five genotypes weighed between 1.2 and $1.8 \mathrm{gm}$, varying with litter size rather than with genotype.

To investigate whether NR1 $1^{\mathrm{R} /+}$ pups were at a selective disadvantage, phenotypically wild-type littermates were removed immediately after birth. Although the mother did not neglect pups isolated in this way, no milk uptake was observed in NR1 ${ }^{\mathrm{R} /+}$ pups, and they still died at P0.

Assuming a tetrameric stoichiometry with two copies of the NR1 subunit per receptor complex (Behe et al., 1995), mice of NR1 ${ }^{\mathrm{R} /+}$ genotype should express $25 \%$ pure wild-type receptors, in addition to $25 \%$ pure mutant receptors and $50 \%$ mixed receptors $\left(\mathrm{NR} 1^{+} / \mathrm{NR} 1^{\mathrm{R}}\right)$. Because a reduced level of wild-type NMDAR expression to $\sim 5 \%$ is compatible with life (Mohn et al., 1999), the reduction of wild-type receptor levels to $25 \%$ cannot be the cause of death in $\mathrm{NR} 1^{\mathrm{R} /+}$ mice. Thus, the $\mathrm{NR} 1^{\mathrm{R}}$ allele represents a gain-of-function mutation.

\section{The NR $1{ }^{\mathrm{R}}$ allele is expressed at wild-type levels}

To investigate whether the NR $1^{\mathrm{R}}$ allele is expressed at wild-type level in our mutant mice, we analyzed expression of NR1 mRNA and protein (Fig. 2).

Northern blot analysis of poly $\left(\mathrm{A}^{+}\right) \mathrm{RNA}$ revealed comparable levels of NR1 mRNA in NR1 ${ }^{\mathrm{R} /-}$ and NR1 $1^{+/-}$mice. This indicates that neither the altered coding sequence nor the remaining loxP site in intron 18 have any obvious effect on NR1 transcription and RNA stability. Furthermore, no aberrant splice variants were detected (Fig. $2 A$ ).

Western blot analysis of membrane fractions showed comparable protein levels for wild-type and mutant subunits. This indicates that the presence of the N598R mutation does not interfere with the regulation of NR1 protein levels in vivo (Fig. $2 B$ ).

\section{Analysis of expression of glutamate and $\mathrm{GABA}_{\mathrm{A}}$ receptor subunits}

Because glutamatergic and GABAergic neurotransmission are influencing each other during development of neural networks (Ben-Ari, 2001), we investigated whether the presence of the NR1 N598R mutation alters the protein levels of other relevant neurotransmitter receptors. To this end, we performed Western blot analysis on brain membrane fractions of all five genotypes probing for NMDAR NR2 subunits, major AMPA receptor and $\mathrm{GABA}_{\mathrm{A}}$ receptor subunits, as well as the NMDAR-associated G-protein-coupled mGluR1 receptor (Fig. 3) (Husi et al., 2000). For all 10 glutamate and $\mathrm{GABA}_{\mathrm{A}}$ receptor proteins that we analyzed, no obvious differences were detected in mice expressing N598R mutant NR1 subunits when compared with mice expressing wild-type NMDARs. In particular, the presence of the NR1 ${ }^{\mathrm{R}}$ 


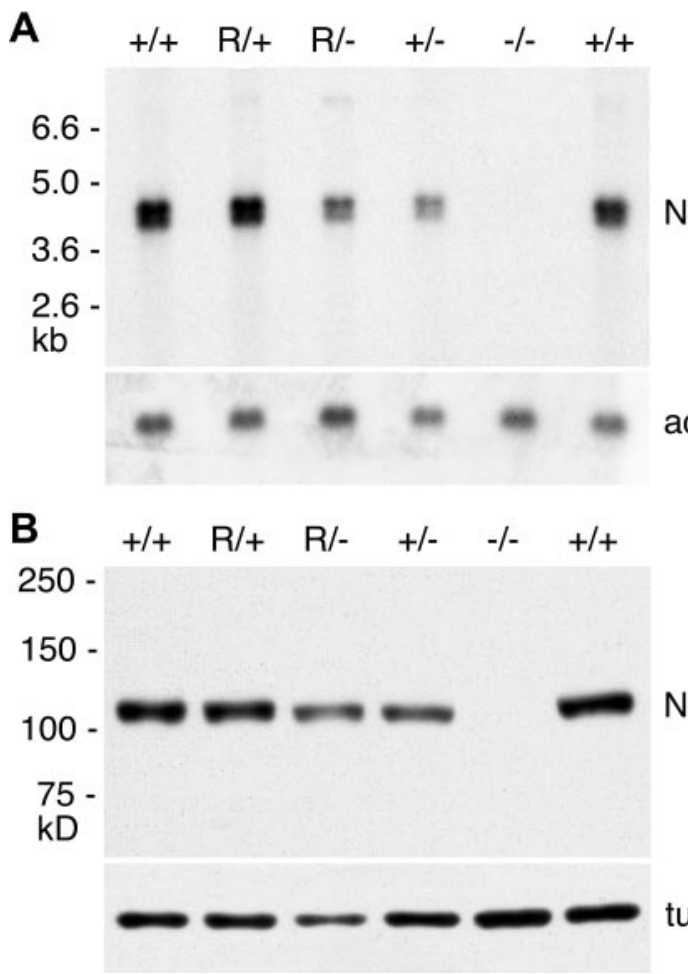

Figure 2. Analysis of NR1 expression in brains from newborn mice. $A$, Northern blots. Three hundred nanograms of poly $\left(\mathrm{A}^{+}\right) \mathrm{RNA}$ from different genotypes were probed with a cDNA fragment covering NR1 exon 15-17 and reprobed for actin as a control. Lanes 1-4 show $\mathrm{NR} 1^{+/+}, \mathrm{NR} 1^{\mathrm{R} /+}, \mathrm{NR} 1^{\mathrm{R} /-}$, and NR1 ${ }^{+/-}$littermates from mating $\mathrm{Il}$, and lanes 5 and 6 show $\mathrm{NR} 1^{-/-}$and NR1 ${ }^{+/+}$littermates from mating III. B, Western blots. Immunoblot analysis of 50 $\mu \mathrm{g}$ of membrane protein from littermates as in $A$ with an antibody binding to the $C$ terminus of NR1. The membrane was reprobed for tubulin. Even prolonged autoradiographic exposures did not detect specific NR1 signals in NR1 ${ }^{-1-}$ samples.

subunits does not lead to reduced NR2B protein levels, contrasting with NR1 ${ }^{-1-}$ knock-out animals, which have downregulated levels of NR2B (Fig. 3A) (Forrest et al., 1994). This indicates that $\mathrm{NR} 1{ }^{\mathrm{R}}$ subunits are comparable with NR1 wild-type subunits with respect to their role in regulating NR2B expression. In summary, Figure 3 indicates that the presence of the mutant NR1 subunit does not have obvious effects on expression of fast neurotransmitter receptors.

\section{NR1 ${ }^{\mathrm{R}}$ mutant NMDARs are functional but lack coincidence} detection properties

We next investigated whether the mutant $\mathrm{NR} 1^{\mathrm{R}}$ subunits form functional NMDARs. Bath application of NMDA resulted in inward currents into neurons from NR1 $1^{\mathrm{R} /+}$ and NR1 $1^{\mathrm{R} /-}$ animals (Table 1). These whole-cell currents were similar in size to those recorded from wild-type tissue ( $\mathrm{NR} 1^{+/+}$and $\mathrm{NR} 1^{+/-}$). APV blocked NMDA-induced currents in all genotypes. No NMDAinduced currents were detected in mice lacking NMDARs $\left(\mathrm{NR} 1^{-1-}\right)$ (Table 1$)$.

NMDA-induced currents in wild-type neurons $\left(\mathrm{NR} 1^{+/+}\right.$and $\mathrm{NR} 1^{+-}$) showed the expected $I-V$ relationship and were sensitive to $\mathrm{Mg}^{2+}$ ions in the expected voltage-dependent manner (Fig. 4, Table 1). In contrast, NMDA-induced responses from neurons, which express only the mutant $\mathrm{NR} 1^{\mathrm{R}}$ subunit, were insensitive to $\mathrm{Mg}^{2+}$ ions, even at a higher concentration (500 $\mu \mathrm{M})$. Currents from neurons that express both $\mathrm{NR} 1^{\mathrm{R}}$ and $\mathrm{NR} 1^{+}$ subunits show an intermediate sensitivity to block by $\mathrm{Mg}^{2+}$, con-
A

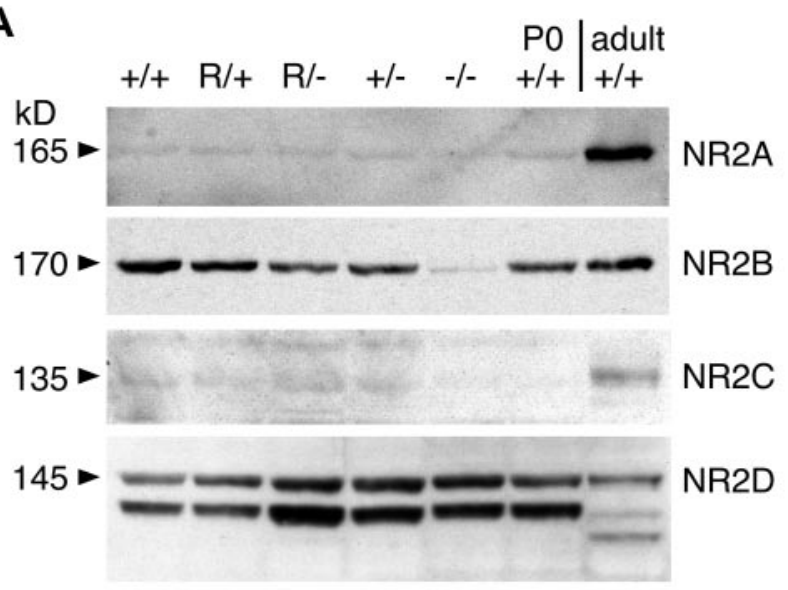

B

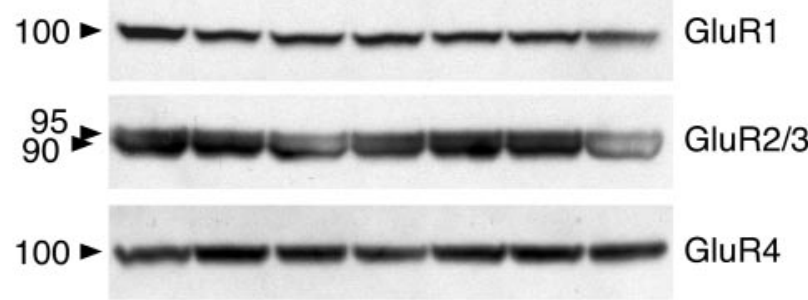

C

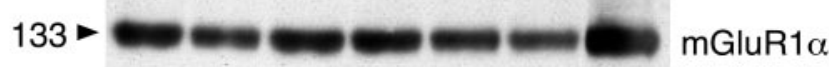

D

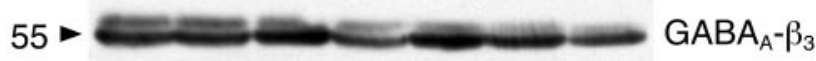

45 ND $\quad \mathrm{GABA}_{\mathrm{A}}-\gamma_{2}$

Figure 3. Western blot analysis of expression of glutamate and $\mathrm{GABA}_{A}$ receptor subunits. Membrane protein fractions $(50 \mu \mathrm{g})$ from whole brains of newborn and adult mice were probed with antibodies to specific receptor subunits. Genotypes of newborn mice $(P O)$ are from matings II and III. Adult wild-type $(+/+)$ is shown as control (ND, not done). A, NMDA receptor subunits. Protein levels of NR2B were found not to be altered in mice expressing the N598R mutant NR1 subunit, whereas absence of the NR1 subunit lead to decreased expression levels of NR2B. NR2A and NR2C were both found to be low in newborn mice of all genotypes compared with higher protein levels in adult mice, suggesting that the NR1 N598R mutation does not affect the protein levels of NR2A and NR2C. NR2D protein levels were at comparable levels in newborn mice of all genotypes. B, AMPA receptor subunits. C, Metabotropic glutamate receptor. D, $G A B A_{A}$ receptor subunits. Expression levels of these subunits were at comparable levels in all NR1 genotypes, suggesting that neither the absence of NR1 nor the N598R point mutation interfere with their expression.

sistent with a heterogeneous receptor population containing pure mutant, mixed, and wild-type receptors.

So far, we showed that NR1 $1^{\mathrm{R} /-}$ animals express functional NMDARs that lack the coincidence detection capability conferred by a voltage-dependent $\mathrm{Mg}^{2+}$ block. In contrast, $\mathrm{NR} 1^{-1-}$ mice do not express NMDARs at all.

\section{Neuroanatomy in N598R mutant mice}

To investigate whether impairment of coincidence detection properties in NR1 $1^{\mathrm{R} /-}$ mice causes neuroanatomical deficits, we 


\begin{tabular}{|c|c|c|c|c|}
\hline Genotype & $\begin{array}{l}+/+ \\
N=4 \\
n=2-12\end{array}$ & $\begin{array}{l}+/- \\
N=3 \\
n=4-8\end{array}$ & $\begin{array}{l}\mathrm{R} /+ \\
N=7 \\
n=16-21\end{array}$ & $\begin{array}{l}\mathrm{R} /- \\
N=6 \\
n=11\end{array}$ \\
\hline \multicolumn{5}{|l|}{$I_{\mathrm{NMDA}}[\mathrm{pA}]$ at $-60 \mathrm{mV}$} \\
\hline No $\mathrm{Mg}^{2+}[1]$ & $-169.8 \pm 26.2$ & $-178.7 \pm 18.0$ & $-369.3 \pm 41.9$ & $-463.6 \pm 74.6$ \\
\hline$+\mathrm{Mg}^{2+}[2]$ & $-166.0 \pm 28.7$ & $-169.2 \pm 35.3$ & $-300.7 \pm 36.9$ & $-435.5 \pm 81.8$ \\
\hline APV block [\%] & $90.85 \pm 1.34$ & $95.50 \pm 1.86$ & $96.67 \pm 1.02$ & $89.26 \pm 2.25$ \\
\hline \multicolumn{5}{|l|}{ Rectification } \\
\hline No $\mathrm{Mg}^{2+}[1]$ & $0.89 \pm 0.096$ & $0.97 \pm 0.14$ & $0.96 \pm 0.10$ & $1.13 \pm 0.16$ \\
\hline$+\mathrm{Mg}^{2+}[2]$ & $2.43 \pm 0.46$ & $2.18 \pm 0.48$ & $1.55 \pm 0.16$ & $1.02 \pm 0.11$ \\
\hline $\mathrm{Mg}^{2+}$ block [\%] at $-90 \mathrm{mV}$ & $44.65 \pm 9.03$ & $52.18 \pm 13.16$ & $18.73 \pm 14.07$ & $4.25 \pm 9.80$ \\
\hline
\end{tabular}

Whole-cell currents were recorded from pyramidal-shaped cells in organotypic hippocampal slice cultures. Currents induced by bath application of $20 \mu \mathrm{m} \mathrm{NMDA}$ and $10 \mu \mathrm{m}$ glycine are given at a holding potential of $-60 \mathrm{mV}$. The percentage of the NMDA-induced current at $-60 \mathrm{mV}$, which was abolished by application of $20 \mu \mathrm{M} \mathrm{D}-A P V$, is given as the APV block. The rectification properties of the cells are quantified as the ratio of three times the current at $+30 \mathrm{mV}$ and the current at $-90 \mathrm{mV}$. The $\mathrm{Mg}^{2+}$ block was determined as the percentage of the current at $-90 \mathrm{mV}$, which was blocked in the presence of $\mathrm{Mg}^{2+}$. [1], Solutions were prepared without adding Mg ${ }^{2+}$, but no measures were taken to eliminate eventual contamination with $\mathrm{Mg}^{2+}$ by the tissue. [2], $\mathrm{Mg}^{2+}$ at $100 \mu \mathrm{m}$ for the NR1 genotypes $+/+$ and $+/-; 500 \mu \mathrm{Mgg}^{2+}$ for R/ + and R/ - . Values are always expressed as mean \pm SEM. $N$, Number of individual animals tested; $n$, number of individual cells tested. Because not every parameter listed could be measured in all cells, a range for $n$ is given. No significant NMDA-induced current $\left(-0.58 \pm 1.86 \mathrm{pA} ; N=3 ; n=11\right.$, without Mg $\left.{ }^{2+}\right)$ was detected in tissue from mice lacking NR1 subunits (-/-).

analyzed brain morphology of various brain regions of newborn mice.

No differences in external brain morphology and weight between $\mathrm{NR} 1^{+/-}$and $\mathrm{NR} 1^{\mathrm{R} /-}$ mice were detected. The early cyanosis and death observed in $\mathrm{NR} 1^{\mathrm{R} /-}$ mice prompted us to investigate the brainstem containing the regulatory centers for respiration, cardiac function, and swallowing. Cytological (Nissl) and histochemical (CO) staining methods did not reveal gross neuroanatomical differences between $\mathrm{NR} 1^{+/-}$and $\mathrm{NR} 1^{\mathrm{R} /-}$ mice in brainstem structures (Fig. $5 E-H$ ). In the cerebellum, no differences were seen with either method. The developing cerebellar granule cell layers were present in both genotypes (Fig. 5A,B, and data not shown). Likewise, in the hippocampus, no significant differences were seen. The layers of the hippocampal cortex were developed equally, and the dentate gyrus was emerging in both genotypes (Fig. 5C,D).

However, within the BSTC, CO staining failed to reveal whisker-related patterns in $\mathrm{NR} 1^{\mathrm{R} /-}$ animals that is found in wildtype mice (Fig. 5G,H) (see below).

\section{Absence of whisker-related patterns in the brainstem of NR1 mutant mice}

NMDAR-mediated coincidence detection and $\mathrm{Ca}^{2+}$ signaling have been implicated in activity-dependent refinement of neuronal connections in developing somatotopic maps (Crair, 1999). Therefore, we analyzed the formation of whisker-related patterns (barrelettes) in the BSTC in our mouse model in detail. Mice with the genetic background we used were born between E18.5 and E20.5 and displayed the full array of large mystacial whiskers.

We found that, in the BSTC of wild-type animals, histochemical (CO staining) but not cytological (Nissl staining) barrelettes can be discerned at birth (Fig. $5 E, G$ ). CO staining reflects the activity of mitochondrial cytochrome oxidase mitochondria, which is particularly high in dendritic arborizations and somata (Wong-Riley and Welt, 1980). The degree of whisker-related patterning was furthest advanced in the subnucleus interpolaris (nVi) (detected in all samples; $n=14$ ) and the least obvious in the principal nucleus of $\mathrm{V}(\mathrm{nVp}$ ) (one of five animals) (Fig. 6A-C). Identical findings have been reported by Ma (1993). No signifi-
R/+
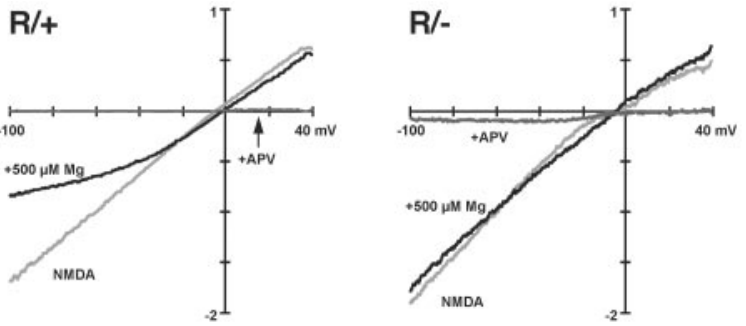

cant difference was seen between $\mathrm{NR} 1^{+/+}$animals and $\mathrm{NR} 1^{+/-}$ animals.

$\mathrm{NR} 1^{\mathrm{R} /-}$ mice express functional NMDARs that lack coincidence detection properties as shown above. However, in newborn pups of this genotype, no whisker-related patterning was noticeable $(n=12)$ (Fig. $6 G-L)$. In fact, throughout the BSTC, $\mathrm{CO}$-stained brainstem sections of $\mathrm{NR} 1^{\mathrm{R} /-}$ mice looked similar to those of NR1 ${ }^{-/-}$mice $(n=5)$ (Fig. $\left.6 D-F\right)$, which are known to lack whisker-related patterning (Li et al., 1994). It appears that $\mathrm{NR} 1^{\mathrm{R} /-}$ mice show a somewhat uneven, granular, but whiskerunrelated, CO staining in the BSTC, in contrast to its amorphous appearance in $\mathrm{NR} 1^{-1-}$ mice.

Blind scoring found whisker-related patterning in $\mathrm{nVi}$ in mice expressing both $\mathrm{NR} 1^{+}$and $\mathrm{NR} 1^{\mathrm{R}}$ subunits $\left(\mathrm{NR} 1^{\mathrm{R} /+}, n=8\right)$ in approximately one-half of the animals, in accordance with Single et al. (2000).

To confirm the results obtained by CO staining, a marker for delineating barrelette boundaries was used, similar to Li et al. (1994). Brainstem sections from wild-type NR1 ${ }^{+/-}$and mutant $\mathrm{NR} 1^{\mathrm{R} /-}$ animals were stained immunohistochemically for the extracellular matrix protein TN-C (Faissner and Steindler, 1995). A pattern complementary to the one seen with $\mathrm{CO}$ staining is revealed in NR1 wild-type mice $\left(\mathrm{NR} 1^{+/-}\right.$) (Fig. $\left.7 A-C\right)$. No whisker-related pattern was found in animals lacking NMDARs $\left(\mathrm{NR} 1^{-/-}\right)$, confirming the usefulness of this stain (Fig. $7 D-F$ ). Equally, no whisker-related pattern is seen in $\mathrm{NR} 1^{\mathrm{R} /-}$ animals, confirming the results obtained by $\mathrm{CO}$ staining for $\mathrm{NR} 1^{\mathrm{R} /-}$ mice.

Together, these results indicate that NMDARs in $N R 1^{\mathrm{R} /-}$ 

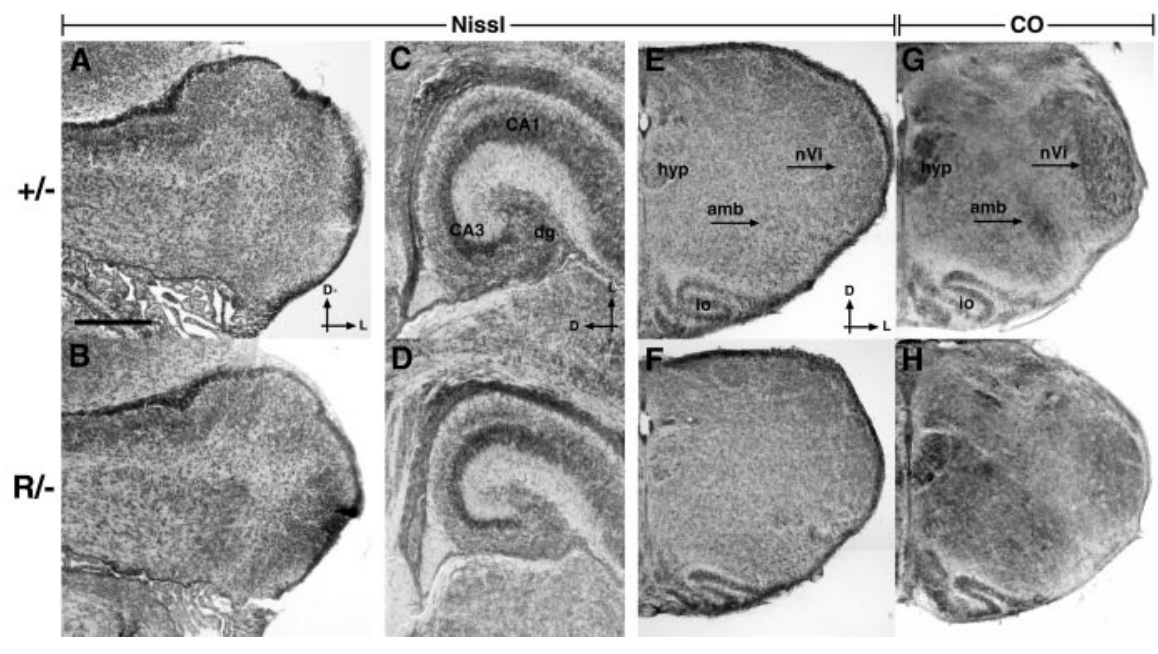

Figure 5. Neuroanatomy of NR1 $1^{+/-}$and NR1 ${ }^{\mathrm{R} /-}$ littermates. Nissl-stained sections of cerebellum $(A, B)$, hippocampus $(C, D)$, and brainstem $(E, F)$, as well as $C O$-stained sections of brainstem $(G, H)$ of newborn NR1 ${ }^{+/-}(A, C, E, G)$ and NR1 ${ }^{\mathrm{R} /-}(B, D, F, H)$ littermates are shown. Both Nissl and $\mathrm{CO}$ staining showed unchanged gross $\mathrm{CNS}$ structure in NR1 ${ }^{\mathrm{R} /-}$ mice compared with contro $\mathrm{NR} 1^{+/-}$mice. However, whisker-related patterns were present in NR1 ${ }^{+/-}$mice $(G)$ and absent in NR1 ${ }^{\mathrm{R} /}{ }^{-}$mice $(H)$. Scale bar: $A-D, 250 \mu \mathrm{m} ; E-H, 500 \mu \mathrm{m}$. Section thickness: $A-D, 15 \mu \mathrm{m} ; E-H, 50 \mu \mathrm{m}$. amb, Nucleus ambiguus; $C A$, cornu ammonis; $d g$, dentate gyrus; hyp, hypoglossal nucleus; $n V i$, subnucleus interpolaris of trigeminal nucleus; $i$, inferior olive; $D$, dorsal; $L$, lateral.
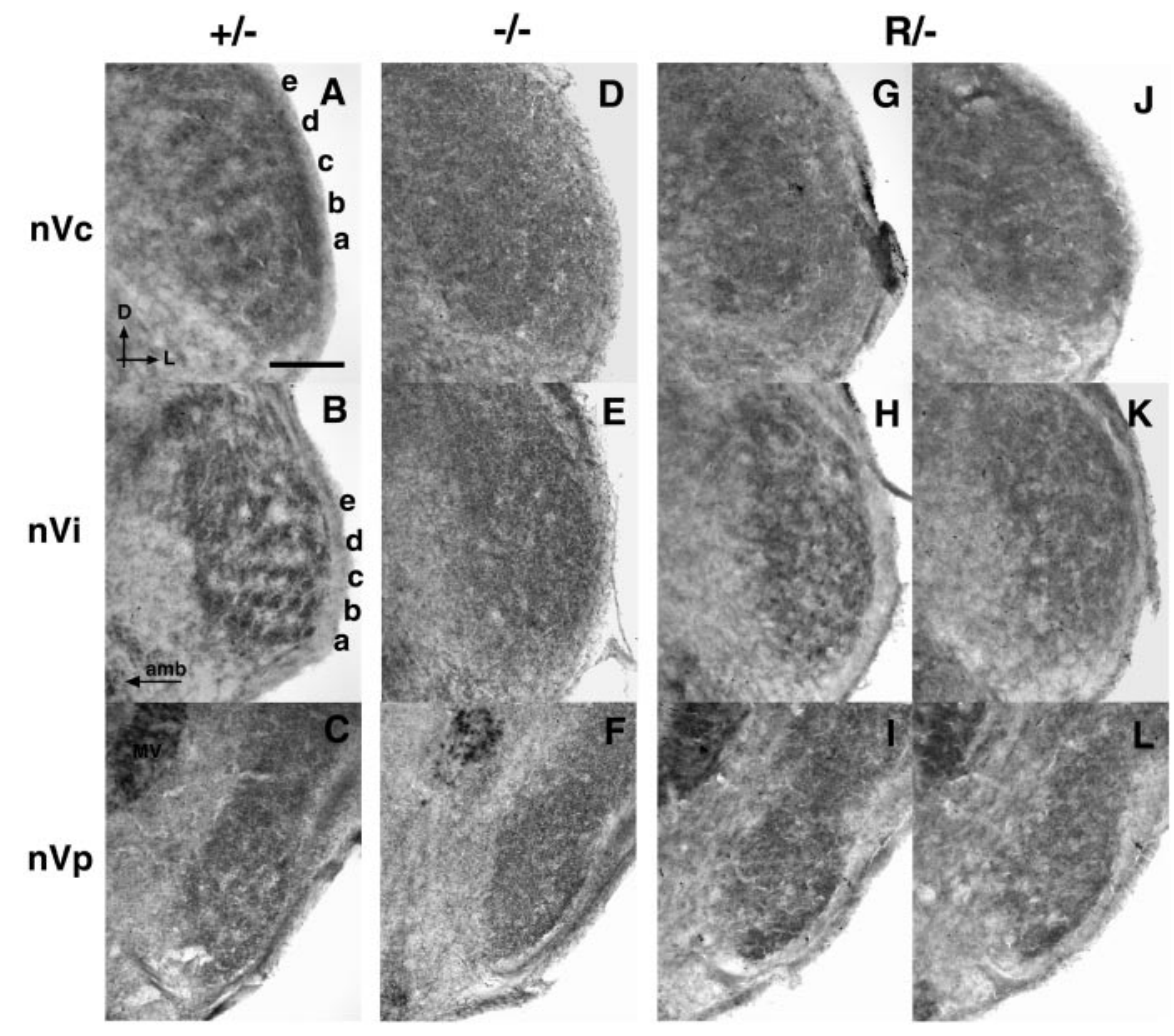

Figure 6. Cytochrome oxidase-stained brainstem sections in newborn NR1 wild-type and mutant mice. $A-L, C O$-stained transversal sections of the $B S T C$ are shown at the level of the $\mathrm{nVC}(A, D, G, J), \mathrm{nVi}(B, E, H, K)$, and $\mathrm{nVp}(C, F, I, L)$ of $\mathrm{NR} 1^{+/-}$ $(A-C), N R 1^{-I-}(D-F)$, and NR1 ${ }^{R /-}(G-L)$ animals. In animals expressing only the wild-type NR1 subunit, whiskerrelated rows $(a-e)$ segregating into individual barrelettes were consistently found in $\mathrm{nVi}(B)$. Emerging whisker-related patterns were usually present in $\mathrm{nVc}(A)$, whereas patterning in $\mathrm{nVp}(C)$ was found only in a small number of animals. In contrast, whisker-related patterns were never found in animals exclusively expressing the N598R mutant NR1 subunit $(G-L)$ or lacking the NR1 subunit $(D-F)$. Examples from two NR1 ${ }^{\mathrm{R} /-}$ animals are shown in $G-I$ and $J-L . M V$, Motor nucleus of $\mathrm{V}$; $a m b$, nucleus ambiguus. Scale bar, $200 \mu \mathrm{m}$. mice fail to mediate the postsynaptic signaling that is required for maturation of the whisker-related somatosensory system.

\section{Normal spatial order and axonal arborization of trigeminal ganglion cell processes in N598R mutant mice}

To ascertain that the absence of barrelettes in $\mathrm{NR} 1^{\mathrm{R} /-}$ mice was not caused by aberrant projection of primary afferents within the BSTC, we used DiI labeling of trigeminal ganglion cells (Erzurumlu and Jhaveri, 1992) on mice that exclusively expressed either wild-type NR1 $\left(\mathrm{NR} 1^{+/+}\right.$, $\mathrm{NR}^{+/-}$) or N598R mutant NR1 subunit $\left(\mathrm{NR} 1^{\mathrm{R} /-}\right)$.

For the analysis of projections of primary afferents, small amounts of DiI crystals were applied to a single whisker on each side of the face. As in wild-type mice, $\mathrm{NR} 1^{\mathrm{R} /-}$ mutants displayed the typical arrangement of large mystacial whiskers in five rows.

In series of transverse sections of all genotypes, the trigeminal tract was labeled, and the arborizations of axon collaterals projecting into the trigeminal nuclei revealed $n V c, n V i$, and $n V p$ as areas separated by poorly stained zones (Fig. $8 A, B, E-H)$. Analysis of the spatial order of single whisker-related DiI patches within $\mathrm{nVc}$ revealed correct correlation with the labeled whisker (Fig. $8 A, B$ ). Furthermore, in both genotypes, the axonal arborization (Fig. 8C,D) appeared to be similar, suggesting that $\mathrm{NR} 1^{\mathrm{R}}$ mutant NMDARs do not disturb the crude topographic mapping of primary trigeminal afferents in the BSTC.

\section{Discussion}

The objective of this study was to evaluate the relevance of coincidence detection and $\mathrm{Ca}^{2+}$ signaling by NMDARs for establishing patterned neuronal connectivity. Previous structure-function studies on recombinant NMDARs have suggested that the introduction of the N598R mutation into the NR1 gene would result in a suitable animal model for this purpose (Burnashev et al., 1992; Katz, 1994).

\section{Lethality of the NR1 N598R mutation}

The lethal phenotype of the NR1 N598R mutation has been described previously (Single et al., 2000). However, in contrast to the previous work, we found that $\mathrm{NR} 1^{\mathrm{R} /+}$ pups generated in our breeding population are unable to survive for more than a few hours after birth. The reason for the somewhat dif- 


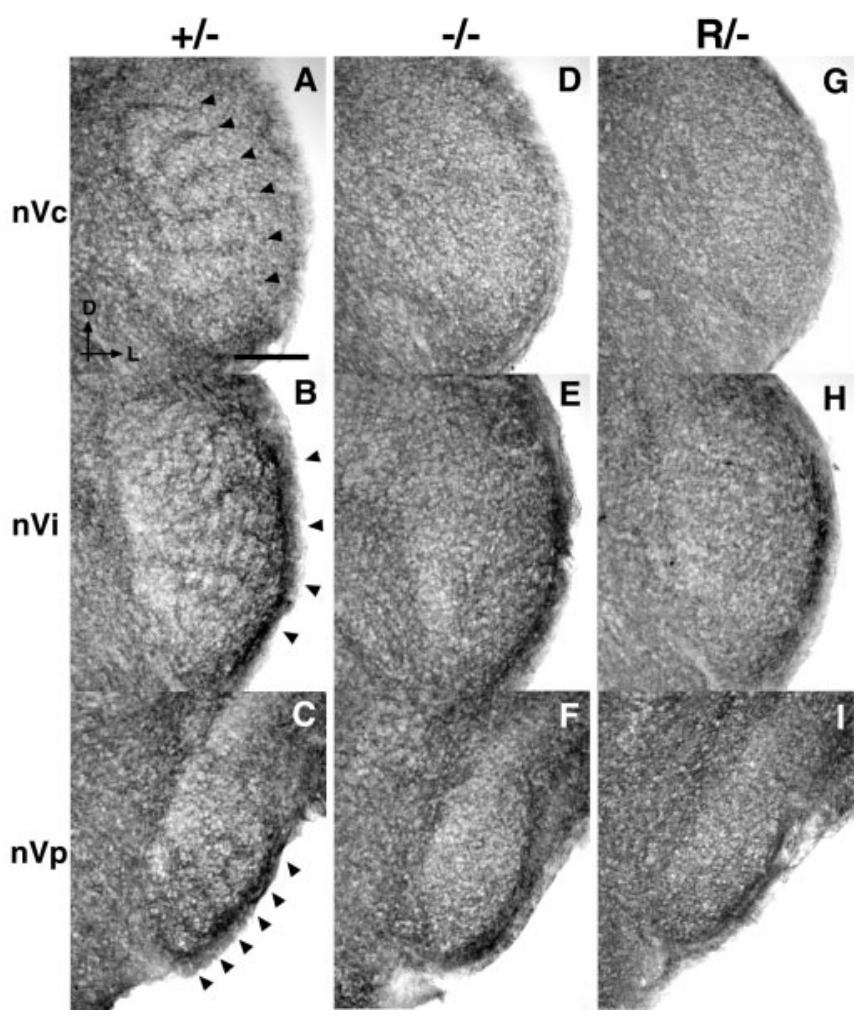

Figure 7. Barrelette detection by immunohistochemistry for Tenascin-C. Transversal section through the BSTC of newborn mice were immunostained with an antibody against the extracellular matrix protein Tenascin-C. The immunopositive pattern reflects the boundaries between barrelettes in control NR $1^{+/-}$animals $(A-C)$. The emerging whisker-related pattern is most distinct in $\mathrm{nVi}(B)$ in which pronounced horizontal and finer vertical boundaries can be seen. Arrowheads denote distinct boundaries delineating whisker-specific rows. No emergent pattern within the BSTC can be discerned in NR1 $1^{\mathrm{R} /-}$ mice $(G-l)$ or in $N R 1^{-/-}$mice $(D-F)$. The contours of the individual BSTC nuclei remain visible, and the sizes of the individual nuclei appear comparable in all three genotypes. Scale bar, $200 \mu \mathrm{m}$.

ferent phenotype between the two animal populations that carry the same mutation is unknown, although subtle differences in genetic background might be relevant.

\section{The mutant NMDARs are functional but lack coincidence detection capability}

Whole-cell NMDA-induced currents, measured in organotypic hippocampal cultures from $\mathrm{NR} 1^{\mathrm{R} /-}$ animals expressing exclusively the mutant NR1 subunits, were comparable in magnitude with those from wild-type animals (Table 1). Single et al. (2000) reported previously that they could not detect agonist-induced currents in enucleated patches from acute hippocampal slices from NR1 $1^{\mathrm{R} /-}$ animals. The agonist-induced currents measured by us in the whole-cell configuration were insensitive to $\mathrm{Mg}^{2+}$, even at high concentrations, as expected from previous work on recombinant receptors containing the NR1 N598R subunit (Burnashev et al., 1992; Schoepfer et al., 1994). Currents from NR $1^{\mathrm{R} /+}$ animals were partly sensitive to $\mathrm{Mg}^{2+}$, consistent with a mixture of wild-type plus mutant receptors and/or receptors containing both wild-type and mutant NR1 subunits (Behe et al., 1995). Recombinant NR1 ${ }^{\mathrm{R}} / \mathrm{NR} 2$ receptor channels are impermeable for $\mathrm{Ca}^{2+}$ (Burnashev et al., 1992), and the $\mathrm{Ca}^{2+}$ reversal potential in $\mathrm{NR} 1^{\mathrm{R} /+}$ animals is shifted as predicted (Single et al., 2000). In summary, we conclude that NR1 ${ }^{\mathrm{R} /-}$ animals express NMDARs with impaired coincidence-dependent $\mathrm{Ca}^{2+}$ signaling at the cell surface.

\section{Absence of gross anatomical alterations in the brains of $\mathrm{NR} 1^{\mathrm{R} /-}$ animals}

$\mathrm{NR} 1^{\mathrm{R}}$ mutant mice differ from NR $1^{-/-}$knock-out mice in their motor and respiratory behavior during the postnatal hours (see Results) (Single et al., 2000). However, like NR1 ${ }^{-/-}$knock-out mice (Forrest et al., 1994; Li et al., 1994), NR1 ${ }^{\mathrm{R}}$ mutant mice did not appear to be developmentally retarded. Indeed, we could not detect any obvious morphological or neuroanatomical abnormalities in $N R 1^{\mathrm{R}}$ mutant mice other than in the brainstem trigeminal nuclei (see below).

Previously, it has been speculated that NMDAR-mediated $\mathrm{Ca}^{2+}$ influx is relevant for migration of cerebellar granule cells (Komuro and Rakic, 1993, 1998). Migration of neocortical neurons has been analyzed in NR1 knock-out mice and was shown not to be affected by the lack of NMDARs (Messersmith et al., 1997). Although we have not performed a detailed analysis of the migration of neurons in $\mathrm{NR} 1^{\mathrm{R}}$ mutant mice, it seems likely from our data that the NR1 N598R mutation alters NMDAR function without interfering with neuronal migration. A region-specific activation of the NR1 ${ }^{\text {Rneo }}$ allele in our mouse model could elucidate this problem.

\section{Exclusive expression of NR1 ${ }^{\mathrm{R}}$ impairs \\ whisker-related patterning}

$\mathrm{NR} 1^{\mathrm{R} /-}$ mice did not show the normal patterning into whiskerrelated rows or barrelettes in the brainstem trigeminal nuclei of newborn mice, when assessed by two independent techniques. Neither histochemical barrelettes, as revealed by CO staining, nor barrelette boundaries, as revealed by TN-C immunohistochemistry, could be detected in these mice. CO histochemistry revealed slight differences in the BSTC between $\mathrm{NR} 1^{-/-}$and $\mathrm{NR} 1^{\mathrm{R} /-}$ mice, whereas TN-C immunohistochemistry showed equally amorphous nuclei. The NR1 $1^{-/-} / \mathrm{NR} 1^{\mathrm{R} /-}$ difference may be explained by the fact that $N R 1^{\mathrm{R} /-}$ mice should have the NMDAR signaling complex in place, which is absent in $\mathrm{NR} 1^{-1-}$ mice. Thus, NR1 $1^{\mathrm{R} /-}$ mice would have the molecular machinery for barrelette formation; however, their signaling pathways are not stimulated in the coordinated manner that is ultimately required for whisker-related pattern formation.

It is still conceivable that the lack of patterning of the postsynaptic cells in the trigeminal nuclei of $\mathrm{NR} 1^{\mathrm{R} /-}$ mice is secondary to altered input into this nucleus. However, this is unlikely. First, both methods revealed normal-sized trigeminal nuclei, either as positively stained (CO) or negatively stained (TN-C) areas. Second, DiI labeling revealed topologically correct targeting of primary afferents in NR1 $1^{\mathrm{R} /-}$ mutant mice, similar to the findings in NR1 ${ }^{-/-}$knock-out mice (Li et al., 1994). Third, the absence of NR2 messages in trigeminal ganglion cells implies that no functional NMDARs are expressed in the primary afferents (Watanabe et al., 1994); therefore, an unaltered input activity pattern is expected. Fourth, the establishment of active synaptic connections between the whisker-related primary afferents and brainstem neurons is not dependent on the presence of NMDARs ( $\mathrm{Li}$ et al., 1994). Together, this is evidence that the lack of barrelette formation in $\mathrm{NR} 1^{\mathrm{R} /-}$ mutants is not attributable to altered input.

Lack of NMDARs in the forebrain impairs whisker-related patterning in the barrel cortex (Iwasato et al., 2000), whereas expression of mutant $\mathrm{NR} 1^{\mathrm{R}}$ subunits in addition to wild-type NR1 subunits (NR1 ${ }^{\mathrm{R} /+}$ ) does not (Single et al., 2000). We found comparable results in the BSTC. NR $1^{\mathrm{R} /+}$ pups showed whiskerrelated patterns at a somewhat reduced prevalence, i.e., in the $\mathrm{nVi}$ of approximately one-half of the pups. These results show that the theoretically expected (Behe et al., 1995) fourfold reduced 

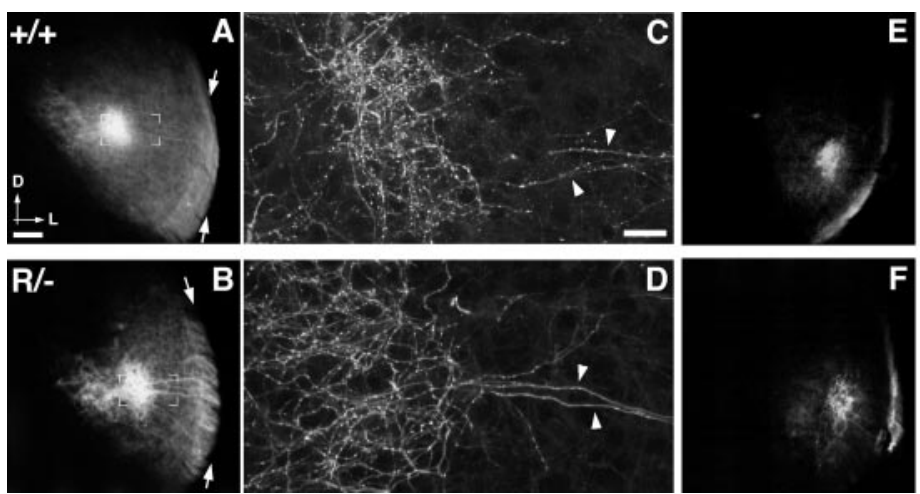

Figure 8. Projection and arborization of single whisker-related trigeminal afferents. Low-magnification, light microscopy $(A, B$ $E-H)$ images of coronal sections of newborn NR1 ${ }^{+/+}(A, E, G)$ and NR1 ${ }^{\mathrm{R} /-}(B, F, H)$ mice through the brainstem at the level of the $\mathrm{nVc}(A, B), \mathrm{nVi}(E, F)$, and $\mathrm{nVp}(G, H)$ after Dil application to a single whisker, $\mathrm{B} 1$ or $\mathrm{B} 2$. Patches of Dil-labeled axonal arborization were centered around the expected topographic location in the trigeminal nuclei. The location $(I)$ of the single whisker-related patch in $\mathrm{nV}$ c for the $\mathrm{B} 1$ whisker was $0.160\left(\mathrm{NR} 1^{+/+}, n=2\right)$ and $0.161\left(\mathrm{NR}^{\mathrm{R} /-}, n=2\right)$ and for the $\mathrm{B} 2$ whisker was 0.239 $\left(\mathrm{NR} 1^{+/+}\right.$or NR1 $\left.{ }^{+/-}, n=8\right)$ and $0.225\left(\mathrm{NR}^{\mathrm{R} /-}, n=6\right)$. Z-projections of stacks containing a series of 66 high-magnification confocal images ( $C, D$, insets of $A$ and $B$, respectively) gave comparable overall impressions of axonal arborizations in both genotypes. Scale bar: $A, B, E-H, 100 \mu \mathrm{m} ; C, D, 20 \mu \mathrm{m}$. Arrows mark the trigeminal tract $(A, B)$. Arrowheads indicate axon collaterals branching off the trigeminal tract $(C, D)$. White line depicts section margin $(G, H) . D$, Dorsal; $L$, lateral.

number of purely wild-type receptors in NR1 ${ }^{\mathrm{R} /+}$ mice is sufficient for whisker-related pattern formation, in accordance with Iwasato et al. (1997).

Absence of whisker-related patterning in the BSTC has been described previously in animals lacking either all NMDARs (Li et al., 1994) or the NR2B-containing subpopulation (Kutsuwada et al., 1996). Because normal patterning is observed in animals lacking the NR2D subunit (Ikeda et al., 1995), these data indicate that the NR2B subunit is critical for whisker-related patterning and cannot be compensated for by the NR2D subunit. We found that protein levels of the NR1 and all of the NR2 subunits (including $\mathrm{NR} 2 \mathrm{~B}$ ) were unchanged in $\mathrm{NR} 1{ }^{\mathrm{R}}$ mutant animals, whereas NR2B subunit levels were downregulated in NR1 knock-out mice (Forrest et al., 1994). Thus, we can rule out the possibility that the observed lack of barrelettes in NR1 ${ }^{\mathrm{R} /-}$ mice was attributable to secondary effects on NR2B function, such as protein level and synaptic localization. This is important because direct interaction between the $\mathrm{C}$ termini of NR2 subunits and MAGUK (membrane-associated guanylate kinase) proteins [via PDZ (postsynaptic density-95/Discs large/zona occludens-1), SH3 (Src homology 3), and guanylyl kinase domains] is assumed to play a major role in anchoring NMDARs in the postsynaptic density (for review, see Scannevin and Huganir, 2000; Sheng and Pak, 2000). For example, genetically engineered mice carrying a deletion of the cytoplasmic $\mathrm{C}$ terminus of the NMDAR subunit NR2B express functional NMDARs at normal levels, but the amount of the truncated subunit at synapses was decreased and whisker-related patterns fail to form in the BSTC (Mori et al., 1998).

\section{Consequences of impaired NMDAR-mediated coincidence detection and $\mathrm{Ca}^{2+}$ influx}

The NR1 N598R mutation results in $\mathrm{Ca}^{2+}$-impermeable NMDARs (Burnashev et al., 1992) and thus abolishes the primary intracellular signal that normally follows coincidence detection (Bliss and Collingridge, 1993). NMDARs are concentrated in the postsynaptic membrane of excitatory synapses, in which they associate via the $\mathrm{C}$ termini of their subunits with a multiprotein scaffolding and signaling complex (Husi et al., 2000). Many interactions of NMDAR subunits with proteins in this complex 289:917-923.
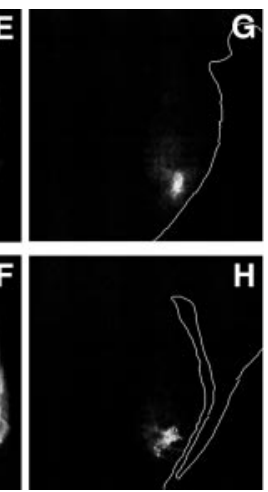

seem to be independent of $\mathrm{Ca}^{2+}$ influx through the NMDAR channel, e.g., interaction with intermediate filaments, adapter protein Yotiao, MAGUK proteins. However, some protein interactions as well as some signaling events are regulated by $\mathrm{Ca}^{2+}$ influx through the NMDAR channel, e.g., $\alpha$-actinin- 2 binding or activation and translocation of $\mathrm{Ca}^{2+}$ /calmodulin kinase II (for review, see Kennedy, 2000; Scannevin and Huganir, 2000; Sheng and Pak, 2000; Bayer and Schulman, 2001). The exact molecular mechanisms that ultimately lead to the absence of whisker-related patterning that we observed remain to be elucidated.

We studied the expression levels of the subunits of the major neurotransmitter receptors and we did not detect any obvious alteration of their protein levels. RNA expression profiling using cDNA array technology also failed to reveal obvious differences. The RNA expression profile of $\mathrm{NR} 1^{\mathrm{R} /+}$ mice, labeled transgenic model by Specht and Schoepfer (2001), their Figure 1, is virtually identical to NR1 $1^{+/+}$"wild-type littermate" controls. However, the expression of mutant NMDARs leads to altered map formation. From that, we conclude that the signaling cascades downstream of coincidence detection and $\mathrm{Ca}^{2+}$ influx act in a highly specific manner without major reprogramming of the neural gene expression pattern. Therefore, most of these signals must be local in nature. This concept of localized signaling cascades fits well with the recent description of spatially well defined signaling complexes (Husi et al., 2000). Highly localized signaling could be an underlying principle of neuronal information processing.

In summary, we showed that NMDARs with impaired coincidence-dependent calcium signaling disturb pattern formation in the brainstem of newborn mice. Region-specific activation of the NR1 N598R allele will provide more detailed insights into the role of NMDAR-mediated signaling in more mature animals and/or regions other than the BSTC, e.g., the primary somatosensory cortex.

\section{References}

Bayer KU, Schulman H (2001) Regulation of signal transduction by protein targeting: the case for CaMKII. Biochem Biophys Res Commun

Behe P, Stern P, Wyllie DJ, Nassar M, Schoepfer R, Colquhoun D (1995) Determination of NMDA NR1 subunit copy number in recombinant NMDA receptors. Proc R Soc Lond B Biol Sci 262:205-213.

Ben-Ari Y (2001) Developing networks play a similar melody. Trends Neurosci 24:353-360.

Bliss TV, Collingridge GL (1993) A synaptic model of memory: long-term potentiation in the hippocampus. Nature 361:31-39.

Bourne HR, Nicoll R (1993) Molecular machines integrate coincident synaptic signals. Cell [Suppl] 72:65-75.

Brandon NJ, Delmas P, Kittler JT, McDonald BJ, Sieghart W, Brown DA, Smart TG, Moss SJ (2000) GABAA receptor phosphorylation and functional modulation in cortical neurons by a protein kinase C-dependent pathway. J Biol Chem 275:38856-38862.

Brandon NJ, Delmas P, Hill J, Smart TG, Moss SJ (2001) Constitutive tyrosine phosphorylation of the $\mathrm{GABA}(\mathrm{A})$ receptor gamma2 subunit in rat brain. Neuropharmacology 41:745-752.

Burnashev N, Schoepfer R, Monyer H, Ruppersberg JP, Gunther W, Seeburg PH, Sakmann B (1992) Control by asparagine residues of calcium permeability and magnesium blockade in the NMDA receptor. Science 257:1415-1419. 
Crair MC (1999) Neuronal activity during development: permissive or instructive? Curr Opin Neurobiol 9:88-93.

Cull-Candy S, Brickley S, Farrant M (2001) NMDA receptor subunits: diversity, development and disease. Curr Opin Neurobiol 11:327-335.

Erzurumlu RS, Jhaveri S (1992) Trigeminal ganglion cell processes are spatially ordered prior to the differentiation of the vibrissa pad. J Neurosci 12:3946-3955.

Erzurumlu RS, Kind PC (2001) Neural activity: sculptor of "barrels" in the neocortex. Trends Neurosci 24:589-595.

Faissner A, Kruse J (1990) J1/tenascin is a repulsive substrate for central nervous system neurons. Neuron 5:627-637.

Faissner A, Steindler D (1995) Boundaries and inhibitory molecules in developing neural tissues. Glia 13:233-254.

Forrest D, Yuzaki M, Soares HD, Ng L, Luk DC, Sheng M, Stewart CL, Morgan JI, Connor JA, Curran T (1994) Targeted disruption of NMDA receptor 1 gene abolishes NMDA response and results in neonatal death. Neuron 13:325-338.

Fox K, Schlaggar BL, Glazewski S, O’Leary DD (1996) Glutamate receptor blockade at cortical synapses disrupts development of thalamocortical and columnar organization in somatosensory cortex. Proc Natl Acad Sci USA 93:5584-5589.

Goodman CS, Shatz CJ (1993) Developmental mechanisms that generate precise patterns of neuronal connectivity. Cell [Suppl] 72:77-98.

Handyside AH, O’Neill GT, Jones M, Hooper ML (1989) Use of BRLconditioned medium in combination with feeder layers to isolate a diploid embryonal stem cell line. Roux Arch Dev Biol 198:48-55.

Higuchi M, Single FN, Kohler M, Sommer B, Sprengel R, Seeburg PH (1993) RNA editing of AMPA receptor subunit GluR-B: a base-paired intronexon structure determines position and efficiency. Cell 75:1361-1370.

Husi H, Ward MA, Choudhary JS, Blackstock WP, Grant SG (2000) Proteomic analysis of NMDA receptor-adhesion protein signaling complexes. Nat Neurosci 3:661-669.

Ikeda K, Araki K, Takayama C, Inoue Y, Yagi T, Aizawa S, Mishina M (1995) Reduced spontaneous activity of mice defective in the epsilon 4 subunit of the NMDA receptor channel. Brain Res Mol Brain Res 33:61-71.

Iwasoto T, Erzurumlu RS, Huerta PT, Chen DF, Sasaoka T, Ulupinar E, Tonegawa S (1997) NMDA receptor-dependent refinement of somatotopic maps. Neuron 19:1201-1210.

Iwasato T, Datwani A, Wolf AM, Nishiyama H, Taguchi Y, Tonegawa S, Knopfel T, Erzurumlu RS, Itohara S (2000) Cortex-restricted disruption of NMDAR1 impairs neuronal patterns in the barrel cortex. Nature 406:726-731.

Jhaveri S, Erzurumlu RS, Chiaia N, Kumar TR, Matzuk MM (1998) Defective whisker follicles and altered brainstem patterns in activin and follistatin knockout mice. Mol Cell Neurosci 12:206-219.

Katz LC (1994) Somatosensory development. A new level of refinement. Curr Biol 4:831-834.

Kennedy MB (2000) Signal-processing machines at the postsynaptic density. Science 290:750-754.

Komuro H, Rakic P (1993) Modulation of neuronal migration by NMDA receptors. Science 260:95-97.

Komuro H, Rakic P (1998) Orchestration of neuronal migration by activity of ion channels, neurotransmitter receptors, and intracellular $\mathrm{Ca}^{2+}$ fluctuations. J Neurobiol 37:110-130.

Kutsuwada T, Sakimura K, Manabe T, Takayama C, Katakura N, Kushiya E, Natsume R, Watanabe M, Inoue Y, Yagi T, Aizawa S, Arakawa M, Takahashi T, Nakamura Y, Mori H, Mishina M (1996) Impairment of suckling response, trigeminal neuronal pattern formation, and hippocampal LTD in NMDA receptor epsilon 2 subunit mutant mice. Neuron 16:333-344.

Li Y, Erzurumlu RS, Chen C, Jhaveri S, Tonegawa S (1994) Whisker-related neuronal patterns fail to develop in the trigeminal brainstem nuclei of NMDAR1 knockout mice. Cell 76:427-437.

Ma PM (1993) Barrelettes-architectonic vibrissal representations in the brainstem trigeminal complex of the mouse. II. Normal post-natal development. J Comp Neurol 327:376-397.
Ma PM, Woolsey TA (1984) Cytoarchitectonic correlates of the vibrissae in the medullary trigeminal complex of the mouse. Brain Res 306:374-379.

Mansour SL, Thomas KR, Capecchi MR (1988) Disruption of the protooncogene int- 2 in mouse embryo-derived stem cells: a general strategy for targeting mutations to non-selectable genes. Nature 336:348-352.

Messersmith EK, Feller MB, Zhang H, Shatz CJ (1997) Migration of neocortical neurons in the absence of functional NMDA receptors. Mol Cell Neurosci 9:347-357.

Mohn AR, Gainetdinov RR, Caron MG, Koller BH (1999) Mice with reduced NMDA receptor expression display behaviors related to schizophrenia. Cell 98:427-436.

Molnar Z, Hannan AJ (2000) Development of thalamocortical projections in normal and mutant mice. In: Mouse brain development (Goffinet AM, Rakic P, eds), pp 293-332. Berlin: Springer.

Mori H, Manabe T, Watanabe M, Satoh Y, Suzuki N, Toki S, Nakamura K, Yagi T, Kushiya E, Takahashi T, Inoue Y, Sakimura K, Mishina M (1998) Role of the carboxy-terminal region of the GluR epsilon2 subunit in synaptic localization of the NMDA receptor channel. Neuron 21:571-580.

Poon CS, Zhou Z, Champagnat J (2000) NMDA receptor activity in utero averts respiratory depression and anomalous long-term depression in newborn mice. J Neurosci 20:RC73(1-6).

Sakurada K, Masu M, Nakanishi S (1993) Alteration of $\mathrm{Ca}^{2+}$ permeability and sensitivity to $\mathrm{Mg}^{2+}$ and channel blockers by a single amino acid substitution in the $N$-methyl-D-aspartate receptor. J Biol Chem 268:410-415

Scannevin RH, Huganir RL (2000) Postsynaptic organization and regulation of excitatory synapses. Nat Rev Neurosci 1:133-141.

Schlaggar BL, Fox K, O’Leary DD (1993) Postsynaptic control of plasticity in developing somatosensory cortex. Nature 364:623-626.

Schoepfer R, Monyer H, Sommer B, Wisden W, Sprengel R, Kuner T, Lomeli H, Herb A, Kohler M, Burnashev N, Günther W, Ruppersberg P, Seeburg P (1994) Molecular biology of glutamate receptors. Prog Neurobiol 42:353-357.

Schwenk F, Baron U, Rajewsky K (1995) A cre-transgenic mouse strain for the ubiquitous deletion of loxP-flanked gene segments including deletion in germ cells. Nucleic Acids Res 23:5080-5081.

Sheng M, Pak DT (2000) Ligand-gated ion channel interactions with cytoskeletal and signaling proteins. Annu Rev Physiol 62:755-778.

Single FN, Rozov A, Burnashev N, Zimmermann F, Hanley DF, Forrest D, Curran T, Jensen V, Hvalby O, Sprengel R, Seeburg PH (2000) Dysfunctions in mice by NMDA receptor point mutations NR1(N598Q) and NR1(N598R). J Neurosci 20:2558-2566.

Specht CG, Schoepfer R (2001) Deletion of the a-synuclein locus in a subpopulation of C57BL/6J inbred mice. BMC Neurosci 2:11.

Stoppini L, Buchs PA, Muller D (1991) A simple method for organotypic cultures of nervous tissue. J Neurosci Methods 37:173-182.

Van der Loos H (1976) Barreloids in mouse somatosensory thalamus. Neurosci Lett 2:1-6.

Watanabe M, Mishina M, Inoue Y (1994) Distinct gene expression of the $\mathrm{N}$-methyl-D-aspartate receptor channel subunit in peripheral neurons of the mouse sensory ganglia and adrenal gland. Neurosci Lett 165:183-186.

Wong-Riley M (1979) Changes in the visual system of monocularly sutured or enucleated cats demonstrable with cytochrome oxidase histochemistry. Brain Res 171:11-28.

Wong-Riley MT, Welt C (1980) Histochemical changes in cytochrome oxidase of cortical barrels after vibrissal removal in neonatal and adult mice. Proc Natl Acad Sci USA 77:2333-2337.

Woolsey TA (1990) Peripheral alteration and somatosensory development. In: Development of sensory systems in mammals (Coleman EJ, ed), pp 461-516. New York: Wiley.

Woolsey TA, Van der Loos H (1970) The structural organization of layer IV in the somatosensory region (SI) of mouse cerebral cortex. The description of a cortical field composed of discrete cytoarchitectonic units. Brain Res 17:205-242. 